\title{
Design and Simulation of a Solar Chimney PV/T Power Plant in Northwest China
}

\author{
Qingjun Liu, ${ }^{1,2}$ Fei Cao $\mathbb{D}^{1,3}$ Yanhua Liu, ${ }^{1}$ Tianyu Zhu, ${ }^{1}$ and Deyou Liu ${ }^{2}$ \\ ${ }^{1}$ College of Mechanical and Electrical Engineering, Hohai University, Changzhou 213022, China \\ ${ }^{2}$ College of Water Conservancy and Hydropower Engineering, Hohai University, Nanjing 210098, China \\ ${ }^{3}$ Sunshore Solar Energy Company Limited, Nantong 226300, China
}

Correspondence should be addressed to Fei Cao; yq.cao@hotmail.com

Received 6 September 2017; Revised 2 December 2017; Accepted 25 December 2017; Published 15 March 2018

Academic Editor: Angel A. Bayod-Rújula

Copyright (c) 2018 Qingjun Liu et al. This is an open access article distributed under the Creative Commons Attribution License, which permits unrestricted use, distribution, and reproduction in any medium, provided the original work is properly cited.

\begin{abstract}
A solar chimney PV/T power plant (SCPVTPP) is proposed. Mathematical models are established for the PV/T solar collector, the chimney, and the power conversion unit, respectively. Performances of the designed SCPVTPP are then simulated. The SCPVTPPs with different PV module areas are finally discussed. It is found that the PV cells hold the highest temperature in the solar collector. Temperature rise of the PV module has significant influences to its power generation. Without cooling, the PV power capacity has an average decrease of $28.71 \%$. The contradictory influences of temperature rise and airflow cooling lead to an $11.81 \%$ decrease of the average power capacity. By adding the power generated by PVT, the total PV-related power contribution increases by $4.72 \%$. With the increase of the solar collector ratio, the temperature rise and the wind velocity both first decrease then increase, the SCPP power productivity decreases linearly, and the PV power productivity increases linearly, whereas the PVT power productivity first increases linearly then increases superlinearly. There is a reversed solar collector ratio, exceeding which the PV generates most power. In this study, solar thermal power takes the major role when the solar $\mathrm{PV}$ area ratio is smaller than 0.055 .
\end{abstract}

\section{Introduction}

The solar chimney power plant (SCPP) consists of three essential parts: a solar collector, a chimney, and a power conversion unit. The schematic of a SCPP is shown in Figure 1(a). Sunlight transfers through the transparent collector cover and heats the ground below. The ground temperature increases and heats the air above it through heat convection. The air temperature increases, leading to the decrease of air density. The density difference then is generated between the ambient air and the air in the solar collector. With the chimney, the air flows towards to the center of the solar collector under buoyancy effect. The air flows through the chimney and runs out of the SCPP at the top of the chimney.

Theoretical, experimental, and case studies of the SCPPs all around the world have concluded that the SCPP is with low power efficiency [1-3], huge solar collector area [4-6], and high chimney [6-9]. Some case studies of SCPPs are summarized in Table 1. Our previous studies have concluded that the reason of SCPP's low efficiency is a compound result of the air characteristics, the solar radiation, and the chimney height $[10,11]$. Air is the only practical working fluid of the SCPP because of the huge air mass flow rate inside the SCPP [11]. For a given location, the solar radiation is fixed. Therefore, it is concluded that the SCPP power capacity can be increased through enlarging the solar collector area or the chimney height $[4,8]$. However, there must be a limit for both these solutions from the techno-economical and safety points of view. A solution that can increase the power capacity but would not increase the chimney height and collector area, or even decrease both of them, is of high significance from the engineering points of view. We then noticed that the 


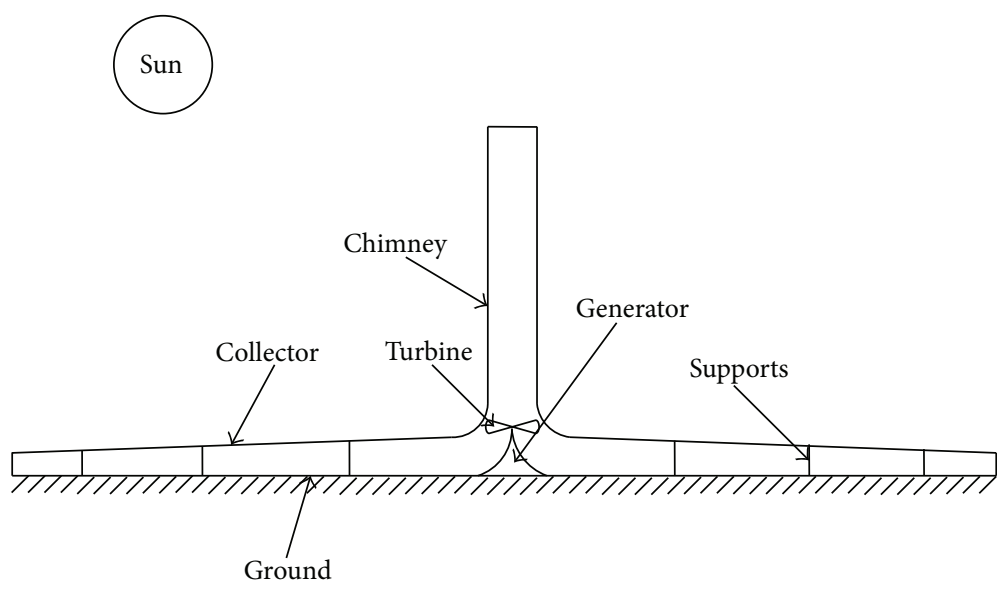

(a)

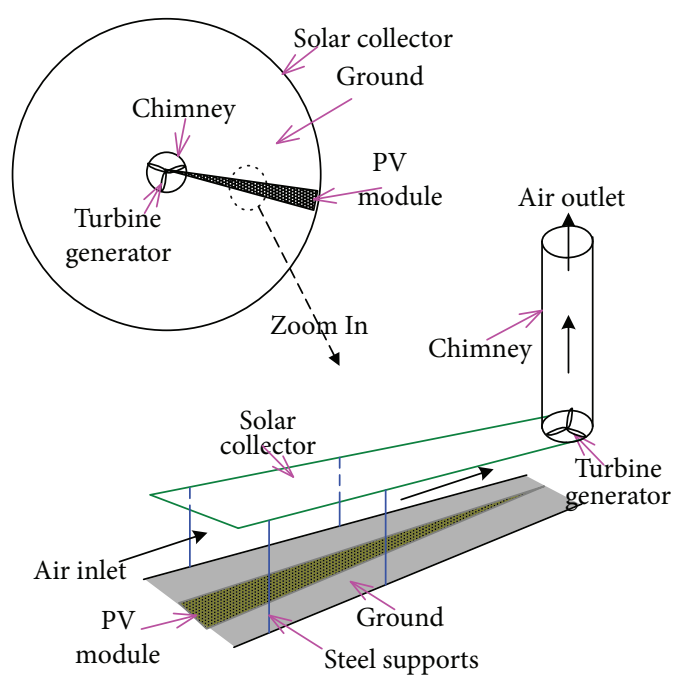

(b)

Figure 1: (a) Schematic of a conventional solar chimney power plant (SCPP). (b) Schematic of a SCPVTPP.

TABLE 1: Parameters of some case studies of SCPPs.

\begin{tabular}{|c|c|c|c|c|c|c|}
\hline Year & Location & $\begin{array}{l}\text { Weather condition } \\
\text { Solar radiation }\end{array}$ & Collector radius & $\begin{array}{l}\text { SCPP parameters } \\
\text { Chimney height }\end{array}$ & Power capacity & Power efficiency \\
\hline 1983 & Manzanares, Spain $[20,21]$ & $1000 \mathrm{~W} / \mathrm{m}^{2}$ & $122 \mathrm{~m}$ & $194.6 \mathrm{~m}$ & $50 \mathrm{~kW}$ & $0.11 \%$ \\
\hline 2003 & Yinchuan, China [22] & $600 \mathrm{~W} / \mathrm{m}^{2}$ & $250 \mathrm{~m}$ & $200 \mathrm{~m}$ & $110-190 \mathrm{~kW}$ & $0.09 \%$ \\
\hline 2010 & Adrar, Algeria [23] & $800 \mathrm{~W} / \mathrm{m}^{2}$ & $250 \mathrm{~m}$ & $200 \mathrm{~m}$ & $140-200 \mathrm{~kW}$ & $0.09 \%$ \\
\hline 2010 & Qinghai-Tibet Plateau [24] ${ }^{1}$ & $807 \mathrm{~W} / \mathrm{m}^{2}$ & $2825 \mathrm{~m}$ & $1000 \mathrm{~m}$ & $92.4 \mathrm{MW}$ & $0.89 \%$ \\
\hline 2012 & 7 cities in Iran $[25]^{2}$ & $640 \mathrm{~W} / \mathrm{m}^{2}$ & $122 \mathrm{~m}$ & $194.6 \mathrm{~m}$ & $75.9 \mathrm{~kW}$ & $0.08 \%$ \\
\hline
\end{tabular}

${ }^{1}$ The authors of [24] did not supply the detailed solar radiation and power capacity in their literature. We calculated the results according to the results supplied in their paper and the solar duration supplied by the China Meteorological Information Center (CMIC). ${ }^{2}$ The solar radiation and power capacity are calculated according to the data supplied by the authors.

huge solar collector, which is empty for the airflow, can be used to place the solar PV modules. On one side, the solar collector area can be used, not influencing the airflow. On the other side, the PV module can be cooled by the airflow in the solar collector by forced heat convection. Correspondingly, a new solar chimney $\mathrm{PV} / \mathrm{T}$ power plant (SCPVTPP) is proposed in Figure 1(b) to fulfill this target. In the system, some solar PV modules are set on the ground of the solar collector. Due to the considerations of safety and construction cost, there are no PV modules in the vertical chimney. The solar radiation transfers through the transparent glass cover and then reaches the PV modules. The insulating layer and the wire connection are set between the PV modules and the ground. Solar radiation transfers through the glass cover and reaches the PV modules. Electricity is generated directly from the PV modules. Meanwhile, some solar radiation is converted into the thermal energy and heats the PV models. The high-temperature PV modules then heat the air above it through heat convection. The other area of the solar collector without the PV modules absorbs the solar radiation directly, which leads to the temperature increase of the ground. The ground then heats the air above it through heat convection. The high-temperature air above the ground and the PV modules then flows into the chimney through buoyancy effect. The solar PV/T technology or device was proposed for the purpose of cooling the PV module to increase its power efficiency [12] and recovering the waste heat to increase the system's total efficiency [13]. It has been widely utilized in the solar water heating (SWH) [14], heating ventilation air conditioning (HVAC) [15], solar-powered buildings [16], and so on. However, the large-scale PV/T system has not been investigated. Considering this, the main tasks in this study include (1) to build a mathematical model for the SCPVTPP, (2) to analyze the performance of the SCPVTPP, and (3) to study the SCPVTPP with different PV areas.

\section{Mathematical Model}

A mathematical model is built for the SCPVTPP. The mathematical model can be divided into three parts, namely, the PVT solar collector model, the chimney model, and the power conversion unit (PCU) model. Practically, the SCPVTPP has a large solar collection area, high chimney height, high PV surface temperature, and high 


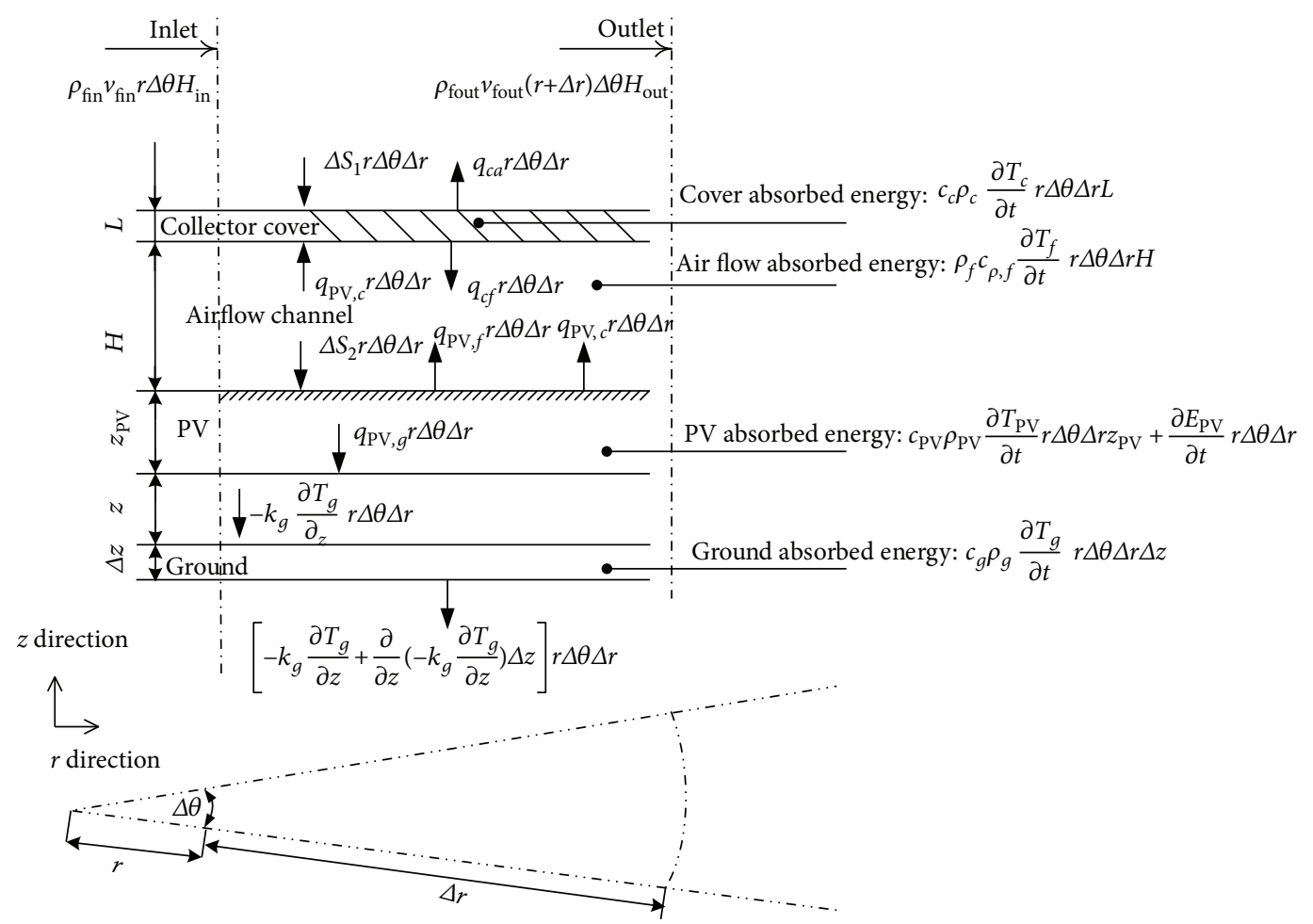

(a)

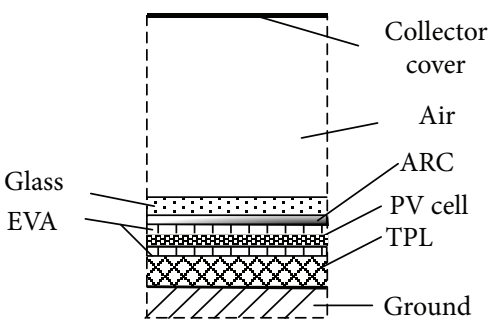

(b)

FIGURE 2: Energy balance of a representative elemental volume in the solar collector and PV: (a) full view and (b) enlarged view of the PVT section.

airflow velocity, compared with the collector height, the collector cover thickness, and the temperature rise in the solar collector are much smaller. Correspondingly, the next assumptions can be made: (a) temperature rises linearly along the airflow direction in the solar collector; (b) ignore the velocity and temperature gradient on the vertical direction in the solar collector; (c) ignore the velocity and temperature gradient on the cross section of the chimney; (d) ignore the temperature difference between the collector upper and back surface; (e) airflow is under adiabatic condition in the chimney; and (f) PV lower surface and ground up surface are connected together.

2.1. PVT Solar Collector Model. Energy balance of a representative elemental volume in the solar collector and $\mathrm{PV}$ is established (Figure 2). In the model, there are three energy balance equations presented in (1), (2), and (3), respectively.
Continuity equation:

$$
\frac{\partial \rho}{\partial t}+\frac{1}{r} \frac{\partial}{\partial r}\left(\rho r v_{r}\right)=0
$$

Momentum equation:

$$
\frac{\partial}{\partial t}\left(\rho v_{r}\right)+\rho v_{r} \frac{\partial v_{r}}{\partial r}=-\frac{\partial p}{\partial r}+\mu\left[\frac{\partial}{\partial r}\left(\frac{1}{r} \frac{\partial}{\partial r}\left(r v_{r}\right)\right)\right] .
$$

Energy equation:

$$
\frac{\partial}{\partial t}\left(\rho c_{p} T\right)+\frac{\partial}{\partial r}\left(c_{p} \rho v_{r} T\right)=\frac{\partial S_{\Phi}}{\partial t} .
$$

Considering the energy balance of a representative elemental volume, as shown in Figure 2(a), the energy source $\partial S_{\Phi} / \partial t$ is

$$
\frac{\partial S_{\Phi}}{\partial t}=q_{c f} r \Delta \theta \Delta r+q_{\mathrm{PV}, f} r \Delta \theta \Delta r+\rho_{f} c_{p, f} \frac{\partial T_{f}}{\partial t} r \Delta \theta \Delta r H,
$$


where the first and the second terms on the right side of (4) are the heat exchange between the collector cover and airflow and between the PV and the airflow, which can be expressed as

$$
\begin{aligned}
q_{c f} r \Delta \theta \Delta r= & \frac{\partial S_{1}}{\partial t} r \Delta \theta \Delta r+q_{\mathrm{PV}, c} r \Delta \theta \Delta r-q_{c a} r \Delta \theta \Delta r \\
& -c_{c} \rho_{c} \frac{\partial T_{c}}{\partial t} r \Delta \theta \Delta r L, \\
q_{\mathrm{PV}, f} r \Delta \theta \Delta r= & \frac{\partial S_{2}}{\partial t} r \Delta \theta \Delta r+\left.k_{\mathrm{PV}, 1} \frac{\partial T_{\mathrm{PV}}}{\partial z}\right|_{z=0} r \Delta \theta \Delta r \\
& -q_{\mathrm{PV}, c} r \Delta \theta \Delta r,
\end{aligned}
$$

where $q_{\mathrm{PV}, c} r \Delta \theta \Delta r$ is the radiation heat exchange between the PV and the collector cover, $q_{c a} r \Delta \theta \Delta r$ is the convection and radiation heat exchange between the collector cover and the ambient, $\left.k_{\mathrm{PV}, 1}\left(\partial T_{\mathrm{PV}} / \partial z\right)\right|_{z=0} r \Delta \theta \Delta r$ is the heat contribution from the PV, $S_{1}$ is the solar radiation absorbed by the collector cover, and $S_{2}$ is the solar radiation absorbed by the PV module or the ground. The PV modules are laid on the ground directly as shown in Figure 2(b). There are six layers in the PV modules, namely, the glass, the anti-reflective coating (ARC), the EVA (ethylene-vinyl acetate), the PV cell, and the Tedlar Polymer Layer (TPL).

Taking a depth of $\Delta z$ of the $i$ th layer inside the PV layer into consideration, we obtain

$$
\begin{aligned}
- & k_{\mathrm{PV}, i} \frac{\partial T_{\mathrm{PV}}}{\partial z_{\mathrm{PV}}} r \Delta \theta \Delta r \Delta z_{\mathrm{PV}} \\
= & {\left.\left[-k_{\mathrm{PV}, i} \frac{\partial T_{\mathrm{PV}}}{\partial z_{\mathrm{PV}}}+\frac{\partial}{\partial z_{\mathrm{PV}}}\left(-k_{\mathrm{PV}, i} \frac{\partial T_{\mathrm{PV}}}{\partial z_{\mathrm{PV}}}\right) \Delta z_{\mathrm{PV}}\right]\right|_{z=z+\Delta z_{\mathrm{PV}}} r \Delta \theta \Delta r \Delta z_{\mathrm{PV}} } \\
& +\frac{\partial E_{\mathrm{PV}}}{\partial t} r \Delta \theta \Delta r \Delta z_{\mathrm{PV}}+c_{\mathrm{PV}, i} \rho_{\mathrm{PV}, i} \frac{\partial T_{\mathrm{PV}}}{\partial t} r \Delta \theta \Delta r \Delta z_{\mathrm{PV}}
\end{aligned}
$$

where $\left[-k_{\mathrm{PV}, i}\left(\partial T_{\mathrm{PV}} / \partial z_{\mathrm{PV}}\right)+\left(\partial / \partial z_{\mathrm{PV}}\right)\left(-k_{\mathrm{PV}, i}\left(\partial T_{\mathrm{PV}} / \partial z_{\mathrm{PV}}\right)\right) \Delta\right.$ $\left.z_{\mathrm{PV}}\right]\left.\right|_{z=z+\Delta z_{\mathrm{pV}}} r \Delta \theta \Delta r \Delta z_{\mathrm{PV}}$ is the heat contribution from upper surface $z$ to the lower surface $z+\Delta z_{\mathrm{PV}}$ and $E_{\mathrm{PV}}=0$ for the layers excluding the PV cell. And at the depth of $z=-z_{\mathrm{PV}}$, we obtain

$$
\begin{aligned}
- & \left.k_{\mathrm{PV}, 6} \frac{\partial T_{\mathrm{PV}}}{\partial z_{\mathrm{PV}}} r \Delta \theta \Delta r \Delta z_{g}\right|_{z=-z_{\mathrm{PV}}} \\
= & {\left.\left[-k_{g} \frac{\partial T_{g}}{\partial z_{g}}+\frac{\partial}{\partial z_{g}}\left(-k_{g} \frac{\partial T_{g}}{\partial z_{g}}\right) \Delta z_{g}\right]\right|_{z=z+\Delta z_{g}} r \Delta \theta \Delta r \Delta z_{g} } \\
& +c_{g} \rho_{g} \frac{\partial T_{g}}{\partial t} r \Delta \theta \Delta r \Delta z_{g} .
\end{aligned}
$$

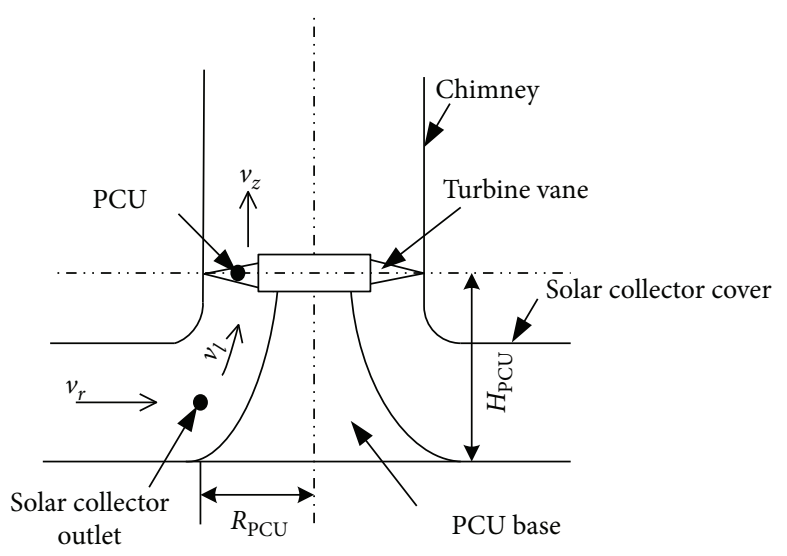

Figure 3: Cross-section of the PCU.

And taking a depth of $\Delta z$ inside the ground into consideration, we obtain

$$
\begin{aligned}
-k_{g} \frac{\partial T_{g}}{\partial z} r \Delta \theta \Delta r \Delta z= & {\left[-k_{g} \frac{\partial T_{g}}{\partial z}+\frac{\partial}{\partial z}\left(-k_{g} \frac{\partial T_{g}}{\partial z}\right) \Delta z\right] r \Delta \theta \Delta r \Delta z } \\
& +c_{g} \rho_{g} \frac{\partial T_{g}}{\partial t} r \Delta \theta \Delta r \Delta z .
\end{aligned}
$$

$\partial E_{\mathrm{PV}} / \partial t$ is the energy output of the PV and can be calculated according to [17]:

$$
E_{\mathrm{PV}}=S_{2} \tau_{c} \eta_{\text {ref }}\left(1-\operatorname{Br}\left(T_{\mathrm{PV}}-T_{\text {ref }}\right)\right),
$$

where $\tau_{c}$ is the transmittance of the PV cover, $\eta_{\text {ref }}$ is the efficiency of PV under standard conditions, $\mathrm{Br}$ is the temperature coefficient, and $T_{\text {ref }}$ is the standard testing temperature of PV.

2.2. Chimney. Continuity equation:

$$
\frac{\partial \rho}{\partial t}+\frac{\partial}{\partial z}\left(\rho v_{z}\right)=0
$$

Momentum equation:

$$
\frac{\partial}{\partial t}\left(\rho v_{z}\right)+\rho v_{z} \frac{\partial v_{z}}{\partial z}=-\frac{\partial p}{\partial z}-\rho g_{z}+\mu \frac{\partial^{2} v_{z}}{\partial z^{2}} .
$$

Energy equation:

$$
\frac{\partial}{\partial t}\left(c_{p} \rho T\right)+\frac{\partial}{\partial z}\left(c_{p} \rho v_{z} T\right)=0 .
$$

For a vertical adiabatic chimney, the pressure difference created in the chimney is

$$
\Delta P_{\text {chi }}=\left(\rho_{a}-\rho_{o}\right) g H_{\text {chi }} .
$$

And the pressure difference between the inlet and outlet of the solar collector is calculated as

$$
\Delta P=\int_{\text {inlet }}^{\text {outlet }} g\left(\rho_{a}-\rho(z)\right) d z,
$$

where $z$ denotes the height. Comparing with the chimney 

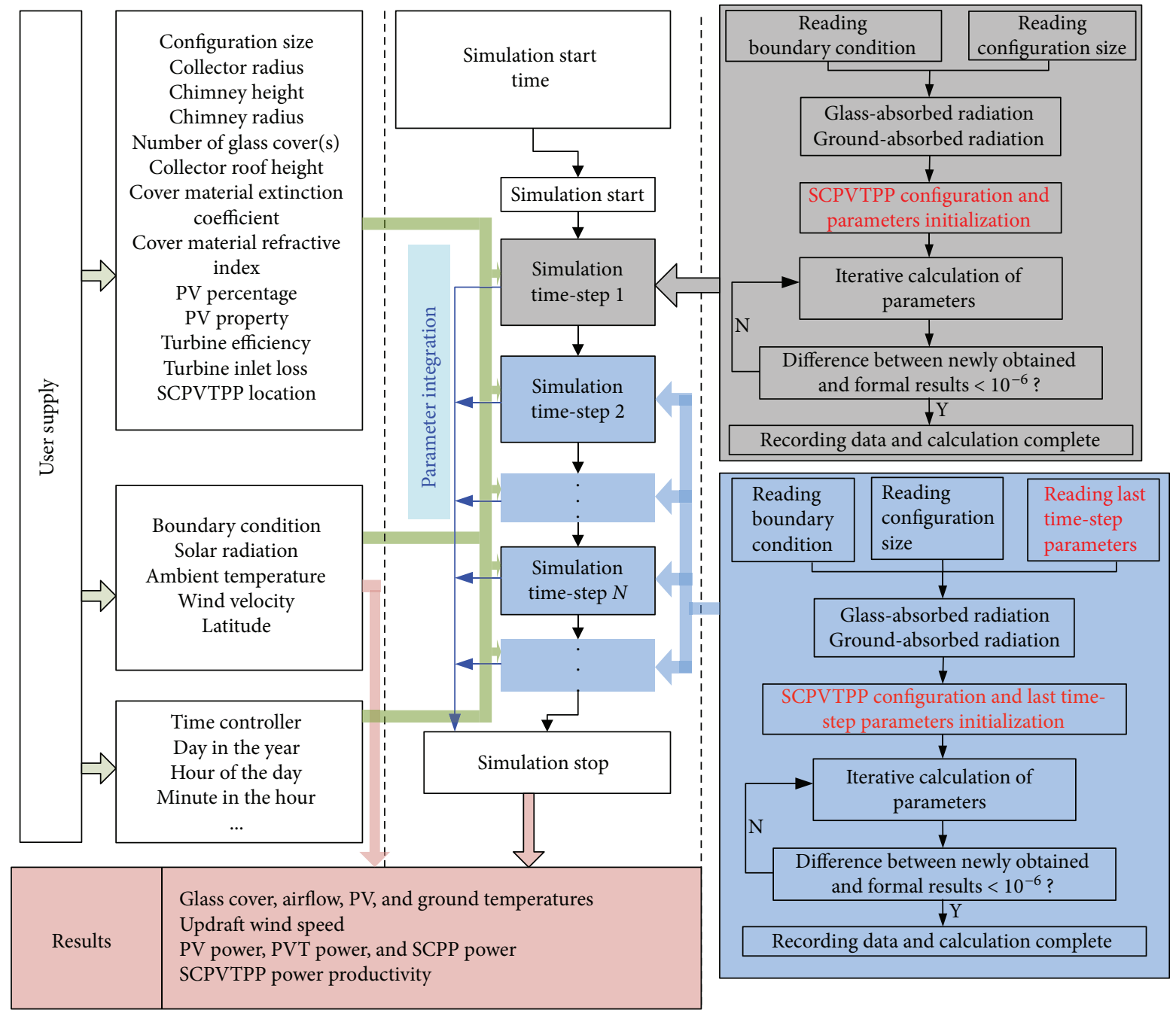

FIGURE 4: Flowchart of the simulation process.

height, the solar collector height is much smaller. Thus, $H_{\text {col }} \approx 0$.

According to Boussinesq assumption and (13) and (14), the momentum equation of the chimney can be simplified as

$$
-\frac{\partial p}{\partial z}-\rho g_{z}+\mu \frac{\partial^{2} v_{z}}{\partial z^{2}}=0 .
$$

2.3. PCU. As the connection section of the PCU is irregular, a randomized coordinate along the power generator surface is built for this area (Figure 3). And we can obtain the following:

Continuity equation:

$$
\frac{\partial \rho}{\partial t}+\frac{\partial}{\partial l}\left(\rho v_{l}\right)=0
$$

Momentum equation:

$$
\frac{\partial}{\partial t}\left(\rho v_{l}\right)+\rho v_{l} \frac{\partial v_{l}}{\partial l}=-\frac{\partial p}{\partial l}-\rho g_{l}+\mu \frac{\partial^{2} v_{l}}{\partial l^{2}}
$$

Energy equation:

$$
\frac{\partial}{\partial t}\left(c_{p} \rho T\right)+\frac{\partial}{\partial l}\left(c_{p} \rho v_{l} T\right)=\frac{\partial}{\partial l}\left(k \frac{\partial T}{\partial l}\right) .
$$

As $H_{\mathrm{PCU}}<<H_{\text {chi }}$ and $R_{\mathrm{PCU}}<<R_{\text {col }}$, we can obtain that

$$
\begin{aligned}
\left.v_{r}\right|_{r=R_{\mathrm{PCU}}} & =\left.v_{l}\right|_{l=0}, \\
\left.v_{z}\right|_{z=H_{\mathrm{PCU}}} & =\left.v_{l}\right|_{l=L_{\mathrm{PCU}}}, \\
H_{\mathrm{PCU}} & \approx 0,
\end{aligned}
$$

where $H_{\text {chi }}$ is the chimney height, $R_{\text {col }}$ is the collector radius, and $L_{\mathrm{PCU}}$ is the length of the PCU channel.

Consequently, the momentum equation can be simplified as

$$
-\frac{\partial p}{\partial l}+\mu \frac{\partial^{2} v_{l}}{\partial l^{2}}=0 .
$$

The generated pressure is consumed by four parts, that is, the friction losses in the collector and the chimney $\Delta P_{f}$, the kinetic energy losses at the turbine inlet $\Delta P_{\text {in }}$, the kinetic 
energy losses at the chimney outlet $\Delta P_{\text {out }}$, and the rest is the effective pressure which is used by the turbine to generate electricity $\Delta P_{t}$.

$$
\begin{aligned}
\Delta P_{\text {chi }} & =\Delta P_{f}+\Delta P_{\text {in }}+\Delta P_{\text {out }}+\Delta P_{t} \\
& =f \frac{L_{\text {th }}}{2 D} \rho v_{l}^{2}+\gamma \frac{1}{2} \rho v_{z}^{2}+\frac{1}{2} \rho_{a} v_{z}^{2}+\Delta P_{t},
\end{aligned}
$$

where $f$ is the friction loss coefficient, $D$ is the hydraulic diameter, $L_{\text {th }}$ is the length of the channel, and $\gamma$ is the turbine inlet loss coefficient.

The power generated by the turbine $P_{\text {ele }}$ is

$$
P_{\text {ele }}=\eta_{t} \Delta P_{t} v_{o} A_{\text {chi }}
$$

2.4. Simulation Methodology. Equations to calculate the coefficients, namely, the heat transfer coefficients, the loss coefficients, the friction loss, and turbine efficiency, follow the previous studies $[1,4,18]$. The equations are converted into the codes to solve the equations. Flowchart of the simulation in this study is shown in Figure 4. As shown in Figure 4, the initial values of the parameters, that is, the collector cover temperature, PV temperature, airflow temperature, and ground temperature, are firstly assumed. An iterative calculation is then made to use the new values to replace the old values. When the differences between any corresponding new and old values are less than the maximal acceptable difference (namely, smaller than $10^{-6}$ ), the iteration process is finally stopped.

\section{Result and Discussion}

3.1. Configuration Sizes of the SCPVTPP. The configuration sizes of the SCPVTPP are shown in Table 2. The SCPVTPP is designed according to 5 and MW SCPP to [19]. And the SCPVTPP is assumed to be operated in Lanzhou. Lanzhou $\left(103.50^{\circ} \mathrm{E}, 36.03^{\circ} \mathrm{N}\right)$ is located in the geographical center of Northwest China. And it has typical Northwestern Chinese climate, that is, strong solar radiation, rare rainfall that diminishes from east to west, dry and cold winter, hot summer, and broad daily temperature width. Its annual global solar radiation is more than $5020 \mathrm{MJ} / \mathrm{m}^{2}$ and sunshine duration is over $2600 \mathrm{~h}$ per year. Its annual mean temperature is $9.8^{\circ} \mathrm{C}$. The properties of six layers in the PV module are shown in Table 3.

3.2. Temperature Increase and Wind Velocity of the SCPVTPP. As the SCPP is dominated by the buoyancy effect, temperature rise in the solar collector is of high significance. Moreover, two contradictory phenomena occur concerning the temperature rise in the PV/T solar collector. On one side, the PV modules are sensitive to the temperature rise. The PV power generation would decrease with the rise of temperature. On the other hand, the updraft wind would enhance with the temperature rising and the generated wind would reduce the temperature of the PV modules. Considering this,

\begin{tabular}{|c|c|c|}
\hline Component & & Value \\
\hline \multirow{6}{*}{ Solar collector } & Collector radius & $625 \mathrm{~m}$ \\
\hline & Collector inlet height & $3 \mathrm{~m}$ \\
\hline & Collector cover emittance & 0.87 \\
\hline & Glass extinction coefficient & $32 \mathrm{~m}^{-1}$ \\
\hline & Glass thickness & $5 \mathrm{~mm}$ \\
\hline & Refractive index & 1.526 \\
\hline \multirow{8}{*}{ PV module } & $\begin{array}{l}\text { Percentage of PV area over } \\
\text { whole solar collector area }\end{array}$ & $30 \%$ \\
\hline & Emittance & 0.9 \\
\hline & Density & $2330 \mathrm{~kg} / \mathrm{m}^{3}$ \\
\hline & Specific heat capacity & $677 \mathrm{~J} /(\mathrm{kg} \cdot \mathrm{K})$ \\
\hline & PV cover transmittance & 0.912 \\
\hline & $\begin{array}{l}\text { PV efficiency under } \\
\text { standard conditions }\end{array}$ & 0.115 \\
\hline & Temperature coefficient $(\mathrm{Br})$ & $0.0045 \mathrm{~K}^{-1}$ \\
\hline & $\begin{array}{c}\text { PV standard } \\
\text { testing temperature }\end{array}$ & $298 \mathrm{~K}$ \\
\hline \multirow{2}{*}{ Chimney } & Height & $550 \mathrm{~m}$ \\
\hline & Radius & $22.5 \mathrm{~m}$ \\
\hline \multirow{6}{*}{ Ground } & Material & Granite \\
\hline & Density & $2640 \mathrm{~kg} / \mathrm{m}^{3}$ \\
\hline & Specific heat capacity & $820 \mathrm{~J} /(\mathrm{kg} \cdot \mathrm{K})$ \\
\hline & Thermal conductivity & $1.73 \mathrm{~W} /(\mathrm{m} \cdot \mathrm{K})$ \\
\hline & Normal emittance & 0.92 \\
\hline & Reflectance & 0.25 \\
\hline \multirow{2}{*}{ Turbine } & Efficiency & 0.8 \\
\hline & Inlet loss coefficient & 0.056 \\
\hline
\end{tabular}
the meteorological data, temperatures, and wind velocity
TABLE 2: Configuration sizes and coefficients of the SCPVTPP.

inside the SCPVTPP are calculated and the results are shown in Figure 5.

Solar radiation and ambient temperature of Lanzhou is shown in Figure 5(a). It is found from the figure that the solar radiation first increases from January to June, with the peak of $689.73 \mathrm{~W} / \mathrm{m}^{2}$. Then the solar radiation decreases till December. The tendency of the ambient temperature is similar with the solar radiation, whereas the highest ambient temperature appears at July. Temperatures of the glass cover, airflow, PV module, and ground and the temperature increase inside the collector at different months in the year are shown in Figure 5(b). It is found from the figure that the temperatures of the glass cover, airflow, PV module, and ground have the same tendency with the ambient temperature, with the peak values at July. Moreover, the PV cell holds the highest temperature among the four temperature groups throughout the year, followed by the ground temperature, the glass cover temperature, and the airflow temperature. Temperature differences between each two groups of temperatures increase from January to July and then decrease till December.

3.3. Power Generation. There are three parts contributing to the power generation in the SCPVTPP, namely, the PV 
TABLE 3: Photovoltaic layer properties.

\begin{tabular}{|c|c|c|c|c|c|}
\hline Layer & Glass & ARC & PV cell & EVA & TPL \\
\hline Thickness $\delta(\mathrm{m})$ & 0.003 & $100 \times 10^{-9}$ & $225 \times 10^{-6}$ & $500 \times 10^{-6}$ & 0.0001 \\
\hline Thermal conductivity $k(\mathrm{~W} / \mathrm{m} \cdot \mathrm{K})$ & 1.8 & 32 & 148 & 0.35 & 0.2 \\
\hline
\end{tabular}

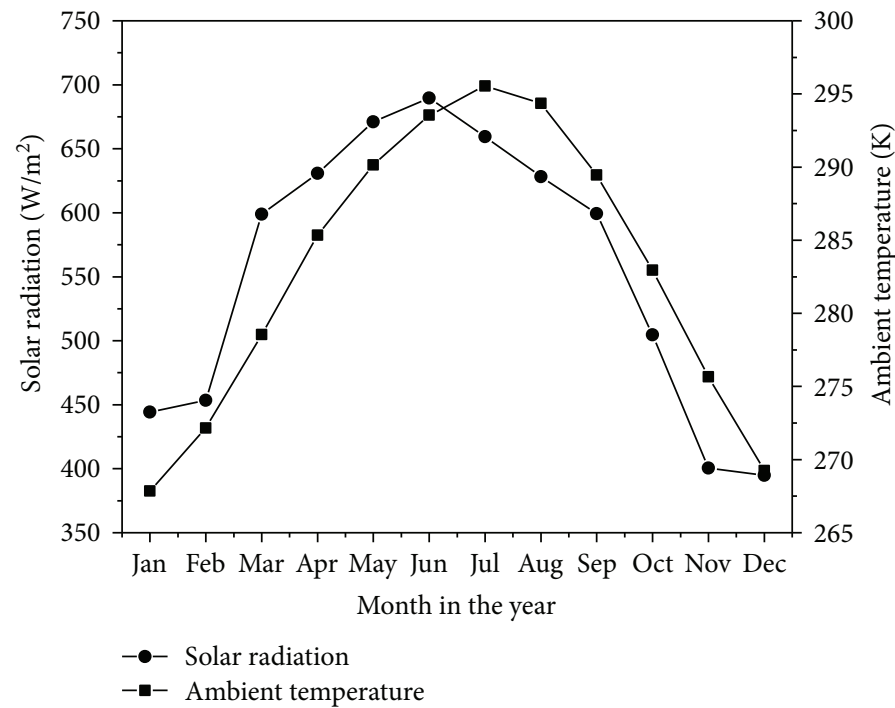

(a)

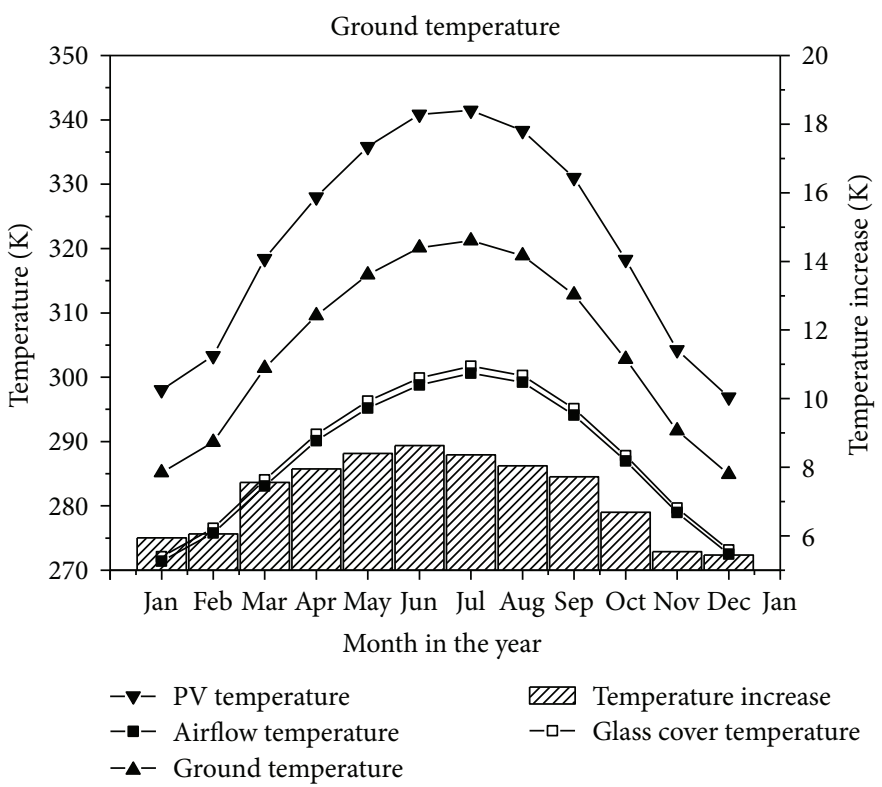

(b)

FIGURE 5: (a) Solar radiation and ambient temperature of the SCPVTPP. (b) Temperatures of the glass cover, airflow, PV module, and ground and temperature increase inside the chimney during different months in the year.

power capacity, the SCPP power capacity, and the PVT power capacity, which, respectively, refers to the power generation directly from the PV modules, the power contribution by the airflow from the solar collector without PV modules, and the power contribution by the airflow heated by the PV modules. Power generations from the PV, the PVT, and the SCPP are shown in Figure 6. It is found from the figure that PV generates much higher power than PVT and SCPP. SCPP generates more power productivity than PVT. The power generates from the solar thermal effect, namely, the power generation from PVT and SCPP is much smaller than that from the PV. This is reasonable as the energy conversion efficiency of SCPP is at $1 \%$ level [1-3], whereas the energy conversion efficiency of $\mathrm{PV}$ is near 


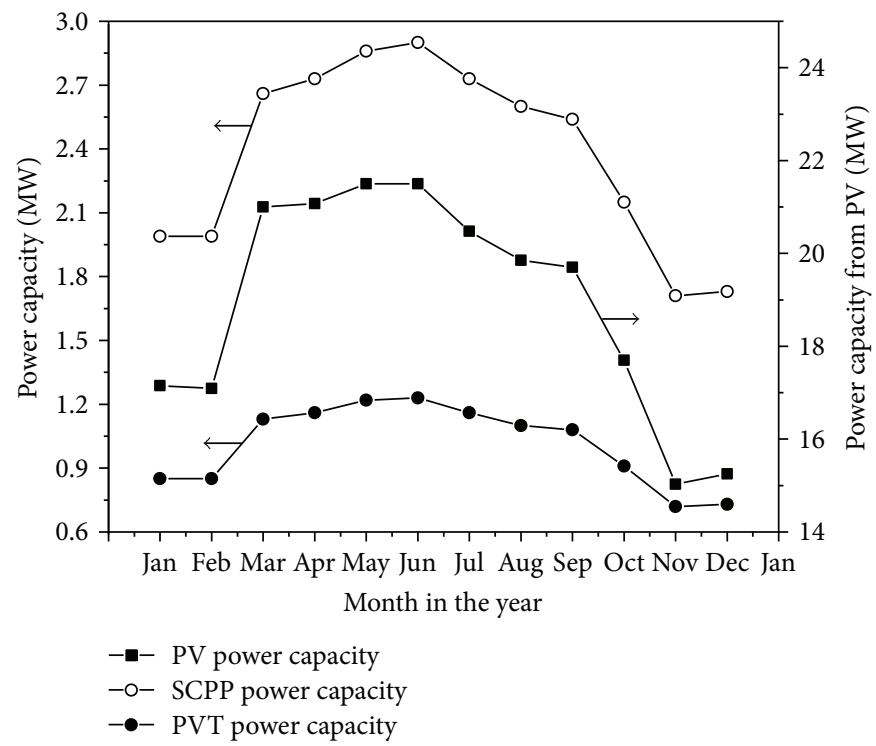

FIgUre 6: Power capacity of the PV, SCPP, and PVT.

$16 \%$ [17]. Power productivities from the PV, PVT, and SCPP have similar tendencies with the solar radiation, except the start and the end of the year for the PV power productivity. It is found in Figure 5(a) that the solar radiation increases from January to February. However, power productivities decrease from January to February in Figure 6 . The reason is that the power productivity is a compound result of the solar radiation and the ambient temperature. It is believed that less power is generated as the PV cell temperature rises according to (9). And the tendency of the ambient temperature rise is much larger than the increase of solar radiation from January to February (Figure 5(a)). The two effects lead to the decrease of power productivity of PV from January to February in Figure 6. This also explains the tendency of PV power productivity from November to December in Figure 6.

As mentioned above, the temperature takes contradictory effect on the PV power generation. The temperature influences on the PV power generation is thus analysed. By taking the PV power generation under ambient temperature as a reference, the PV model power, the PVT power contribution, and the total PV-related power contribution (PV + PVT) in the present study and the PV power generation without airflow cooling are then compared in Table 4 . In can be found from Table 4 that the temperature rise of the PV module has significant influences to its power generation. Without cooling, the PV power capacity has an average decrease of $28.71 \%$. The contradictory influences of temperature rise and airflow cooling lead to an $11.81 \%$ decrease of the average power capacity, reflecting the temperature rise which takes the major role in the SCPVTPP. The PVT power contribution is much smaller than the others. But adding the power generated by the PVT effect, the total PV-related power contribution would increase by $4.72 \%$. And there are some conditions, that is, in January, February, November, and December, the total PV-related power contribution is larger than the reference $P_{\mathrm{PV} \_\mathrm{Ta}}$. The reason is that the PV models' temperatures are low in these months, due to also low ambient temperatures. And the system takes full advantage of PV modules and generated updraft winds in these months.

3.4. SCPVTPP with Different PV Areas. The performances of the SCPVTPP is discussed in Figures 5(b) and 6 for the case that PV area takes $30 \%$ of the whole solar collector. However, there are some cases that the PV area can take more or less percentage to the whole solar collector. The SCPVTPP performances and power productivities under different solar collector area ratios are then calculated with the same methodology as the case of $30 \%$. The results are shown in Figures 7(a) and 7(b). It is found in Figure 7(a) that with the increase of the solar collector ratio, the temperature rise and the wind velocity both first decrease then increase. However, the valleys of the temperature rise and the wind velocity appear at different solar collector ratios. The lowest temperature rise is located at the solar collector ratio of 0.4 , whereas the lowest wind velocity is located at the solar collector ratio of 0.6. Moreover, tendencies of the temperature rise and the wind velocity differ from each other. The temperature rise first decreases gradually and then increases gradually. But the wind velocity first decreases slowly and then increases quickly. It is found from Figure 7 (b) that with the increase of the solar collector ratio, the SCPP power productivity decreases linearly and the PV power productivity increases linearly, whereas the PVT power productivity first increases linearly then increases superlinearly. The total power productivity increases with the solar collector ratio rises. There is a reversed solar collector ratio, exceeding the PV which generates most of the power. With detailed calculation, it is found that the solar collector ratio is 0.055 , which means that solar thermal power takes the major role of power generation when the solar PV area ratio is smaller than 0.055 . 


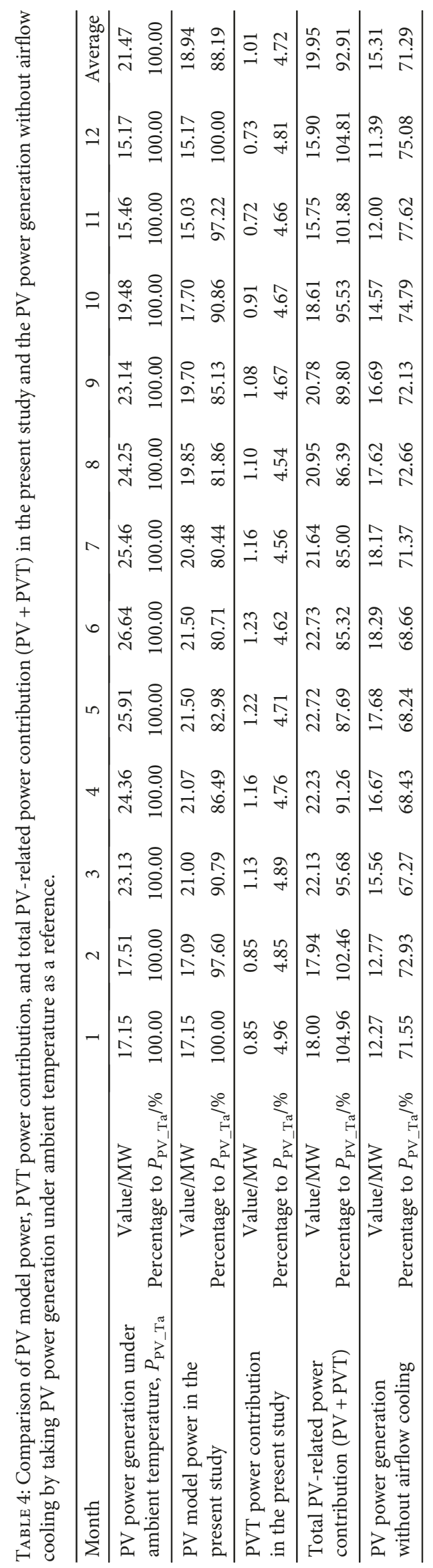




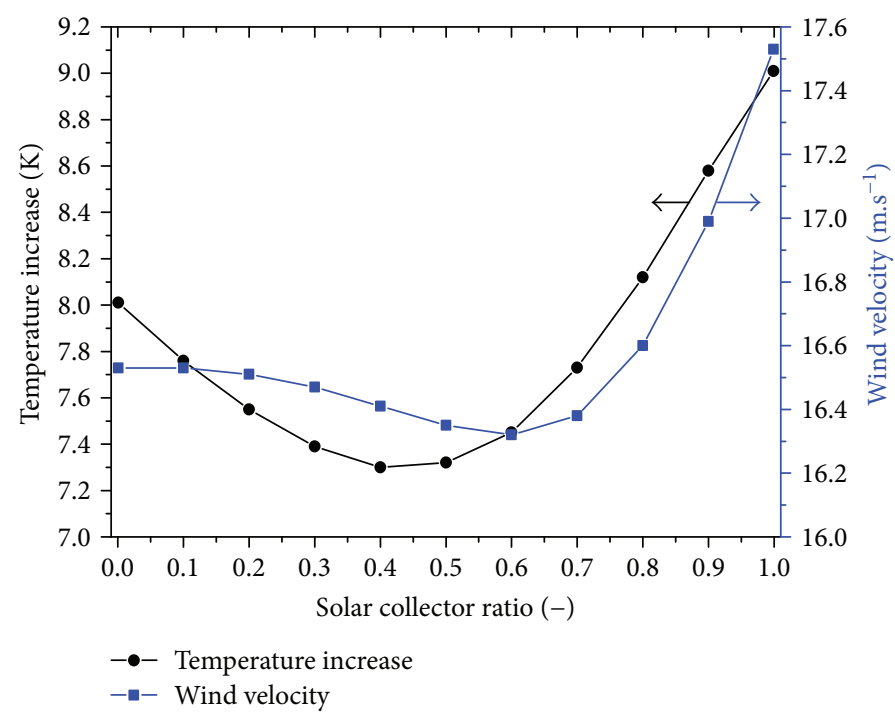

(a)

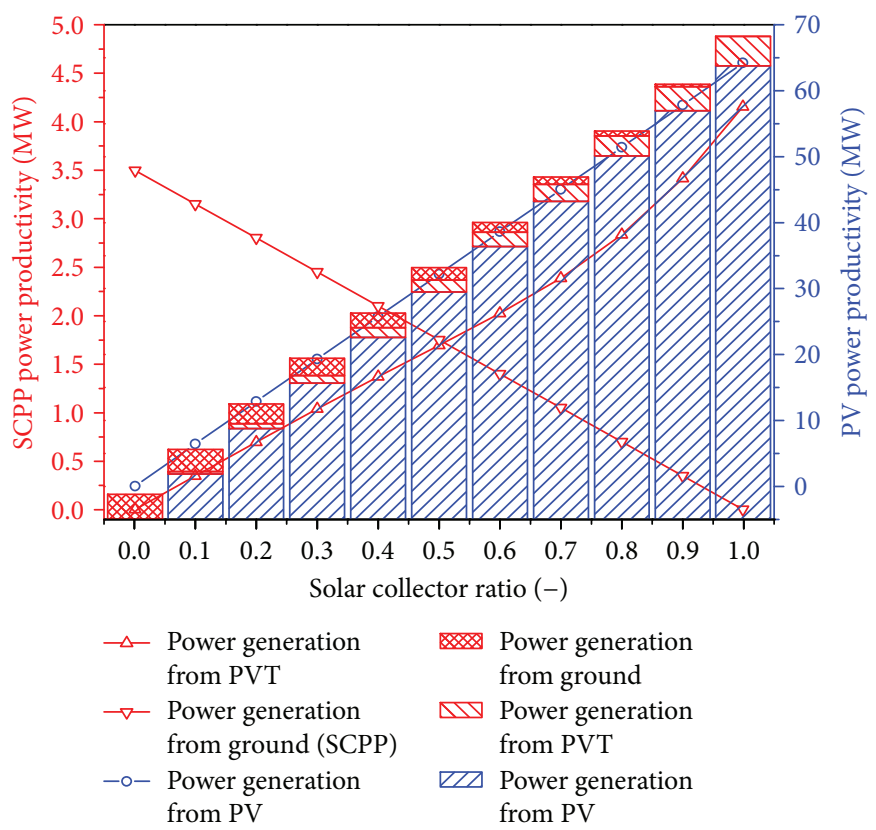

(b)

Figure 7: (a) Temperature increase and wind velocity in the SCPVTPP under different solar collector ratios. (b) Power generation from PVT, $\mathrm{PV}$, and ground and the total power generation under different solar collector ratios.

\section{Conclusions}

The SCPP has a large solar collector area, which can be used to lay the PV modules. A SCPVTPP is proposed and studied in this study. A mathematical model is established for the proposed system. The SCPVTPP performances and the power productivities under different solar collector ratios are then discussed. It can be concluded from this study that

(1) The PV cells hold the highest temperature in the solar collector throughout the year, followed by the ground temperature, the glass cover temperature, and the airflow temperature. The temperature rise of the PV module has significant influences to its power generation. Without cooling, the PV power capacity has an average decrease of $28.71 \%$. The contradictory influences of temperature rise and airflow cooling lead to an $11.81 \%$ decrease of the average power capacity. By adding the power generated by PVT, the total PVrelated power contribution increases by $4.72 \%$.

(2) With the increase of the solar collector ratio, the temperature rise and the wind velocity both first decrease then increase. The lowest temperature rise is located at the solar collector ratio of 0.4 , whereas 
the lowest wind velocity is located at the solar collector ratio of 0.6 .

(3) With the increase of the solar collector ratio, the SCPP power productivity decreases linearly and the PV power productivity increases linearly, whereas the PVT power productivity first increases linearly then increases superlinearly.

(4) There is a reversed solar collector ratio, exceeding the $\mathrm{PV}$ which generates most of the power. In this study, solar thermal power takes the major role when the solar PV area ratio is smaller than 0.055 .

\section{Nomenclature}

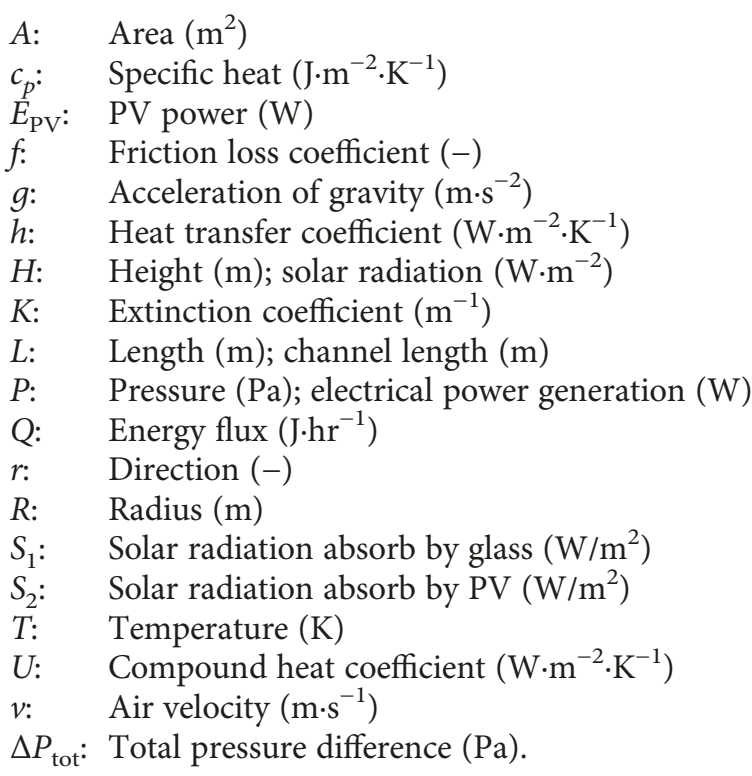

\section{Greek Symbols}

$\Delta:$ Difference (-)

$\rho:$ Air density $\left(\mathrm{kg} \cdot \mathrm{m}^{-3}\right)$; reflectance $(-)$

$\theta$ : Angle $\left({ }^{\circ}\right)$; direction $(-)$

$\gamma$ : Turbine inlet loss coefficient $(-)$

$\mu$ : Dynamic viscosity $\left(\mathrm{kg} \cdot \mathrm{m}^{-1} \cdot \mathrm{s}^{-1}\right)$

$\eta_{\mathrm{t}}$ : Turbine efficiency.

Subscripts
$a: \quad$ Ambient
$c:$ Collector cover
col: Collector
chi: Chimney
$f: \quad$ Airflow
gro: Ground
in: Turbine inlet
$o: \quad$ Outlet of the solar collector
out: Outlet of the chimney
PV: Photovoltaic.

\section{Conflicts of Interest}

The authors declare that they have no conflicts of interest.

\section{Acknowledgments}

This research was supported by the National Natural Science Foundation of China (Grant no. 51506043), the Natural Science Foundation of Jiangsu Province (Grant no. BK20141153), the "Dayu Scholar" Foundation of Hohai University, and the China Scholarship Council (Grant no. 201706715058).

\section{References}

[1] F. Cao, L. Zhao, and L. Guo, "Simulation of a sloped solar chimney power plant in Lanzhou," Energy Conversion and Management, vol. 52, no. 6, pp. 2360-2366, 2011.

[2] T. Z. Ming, Y. Zheng, C. Liu, W. Liu, and Y. Pan, "Simple analysis on thermal performance of solar chimney power generation systems," Journal of the Energy Institute, vol. 83, no. 1, pp. 6-11, 2010.

[3] X. Zhou, F. Wang, and R. M. Ochieng, "A review of solar chimney power technology," Renewable and Sustainable Energy Reviews, vol. 14, no. 8, pp. 2315-2338, 2010.

[4] S. Larbi, A. Bouhdjar, and T. Chergui, "Performance analysis of a solar chimney power plant in the southwestern region of Algeria," Renewable and Sustainable Energy Reviews, vol. 14, no. 1, pp. 470-477, 2010.

[5] R. Sangi, "Performance evaluation of solar chimney power plants in Iran," Renewable and Sustainable Energy Reviews, vol. 16, no. 1, pp. 704-710, 2012.

[6] C. D. Papageorgiou and P. P. Katopodis, "A modular solar collector for desert floating solar chimney technology," in Energy, Environment, Ecosystems, Development and Landscape Architecture, pp. 126-132, WSEAS Press, Athens, Greece, 2009.

[7] X. Zhou, J. Yang, B. Xiao, G. Hou, and Y. Wu, "Numerical investigation of a compressible flow through a solar chimney," Heat Transfer Engineering, vol. 30, no. 8, pp. 670-676, 2009.

[8] X. Zhou, M. A. D. S. Bernardes, and R. M. Ochieng, "Influence of atmospheric cross flow on solar updraft tower inflow," Energy, vol. 42, no. 1, pp. 393-400, 2012.

[9] S. Nizetic, N. Ninic, and B. Klarin, "Analysis and feasibility of implementing solar chimney power plants in the Mediterranean region," Energy, vol. 33, no. 11, pp. 1680$1690,2008$.

[10] F. Cao, H. Li, L. Zhao, T. Bao, and L. Guo, "Design and simulation of the solar chimney power plants with TRNSYS," Solar Energy, vol. 98, pp. 23-33, 2013.

[11] F. Cao, L. Zhao, H. Li, and L. Guo, "Performance analysis of conventional and sloped solar chimney power plants in China," Applied Thermal Engineering, vol. 50, no. 1, pp. 582592, 2013.

[12] J. A. Duffie and W. A. Beckman, Solar Engineering of Thermal Processes, John Wiley \& Sons, New York, NY, USA, 2006.

[13] E. C. J. Kern and M. C. Russell, "Combined photovoltaic and thermal hybrid collector systems," in IEEE Photovoltaic Specialists Conference, vol. 1, pp. 1153-1157, Washington, DC, USA, 1978.

[14] L. W. Florschuetz, "Extension of the Hottel-Whillier model to the analysis of combined photovoltaic/thermal flat plate collectors," Solar Energy, vol. 22, no. 4, pp. 361-366, 1979. 
[15] A. A. Hegazy, "Comparative study of the performances of four photovoltaic/thermal solar air collectors," Energy Conversion and Management, vol. 41, no. 8, pp. 861-881, 2000.

[16] H. Yang, J. Burnett, and J. Ji, "Simple approach to cooling load component calculation through PV walls," Energy and Buildings, vol. 31, no. 3, pp. 285-290, 2000.

[17] G. Chao, Numerical and Experimental Study of Tri-Functional Photovoltaic/Thermal Collector [Ph.D. Thesis], University of Science and Technology of China, China, 2015.

[18] X. Zhou and Y. Xu, "Solar updraft tower power generation," Solar Energy, vol. 128, pp. 95-125, 2016.

[19] J. Schlaich, R. Bergermann, W. Schiel, and G. Weinrebe, "Design of commercial solar updraft tower systems-utilization of solar induced convective flows for power generation," Journal of Solar Energy Engineering, vol. 127, no. 1, pp. 117124, 2005.

[20] W. Haaf, "Solar chimneys. Part II: preliminary test results from the Manzanares pilot plant," International Journal of Solar Energy, vol. 2, no. 2, pp. 141-161, 1984.

[21] J. Schlaich, The Solar Chimney: Electricity from the Sun, Axel Menges, Stuttgart, Germany, 1995.

[22] Y. J. Dai, H. B. Huang, and R. Z. Wang, "Case study of solar chimney power plants in Northwestern regions of China," Renewable Energy, vol. 28, no. 8, pp. 1295-1304, 2003.

[23] M. O. Hamdan, "Analysis of a solar chimney power plant in the Arabian gulf region," Renewable Energy, vol. 36, no. 10, pp. 2593-2598, 2011.

[24] X. Zhou, F. Wang, J. Fan, and R. M. Ochieng, "Performance of solar chimney power plant in Qinghai-Tibet plateau," Renewable and Sustainable Energy Reviews, vol. 14, no. 8, pp. 2249-2255, 2010.

[25] A. Asnaghi and S. M. Ladjevardi, "Solar chimney power plant performance in Iran," Renewable and Sustainable Energy Reviews, vol. 16, no. 5, pp. 3383-3390, 2012. 

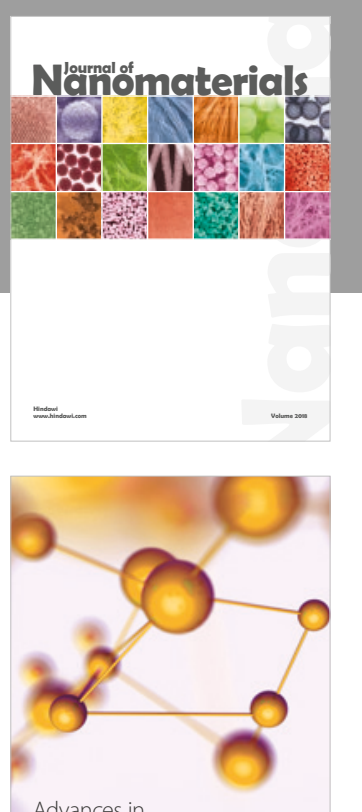

Physical Chemistry
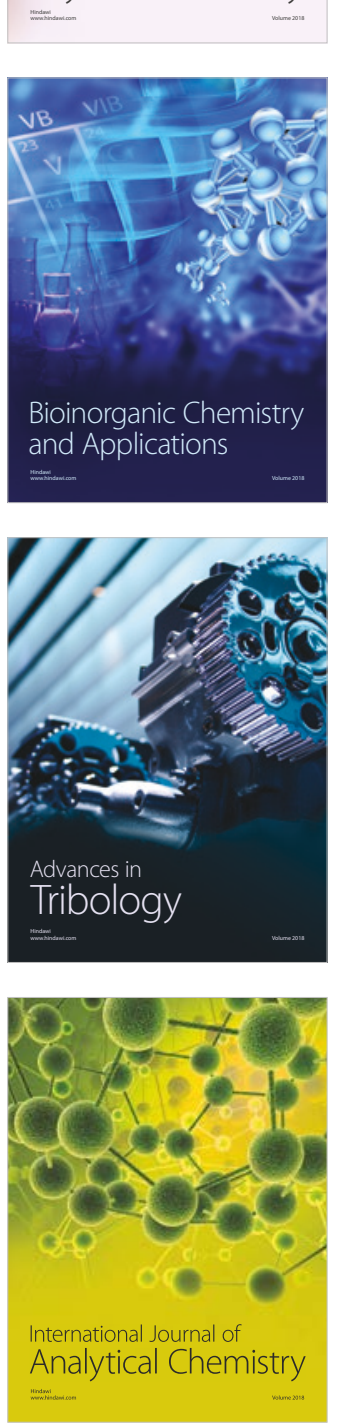

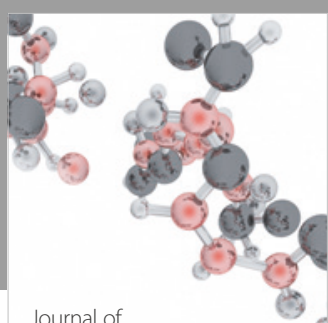

Analytical Methods

in Chemistry

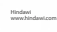

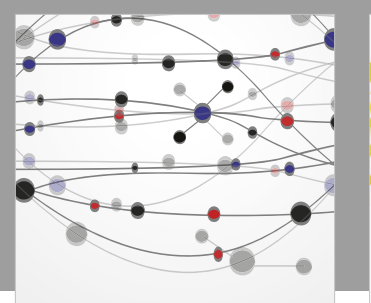

The Scientific World Journal

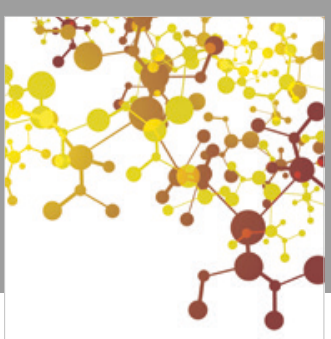

Journal of

Applied Chemistry
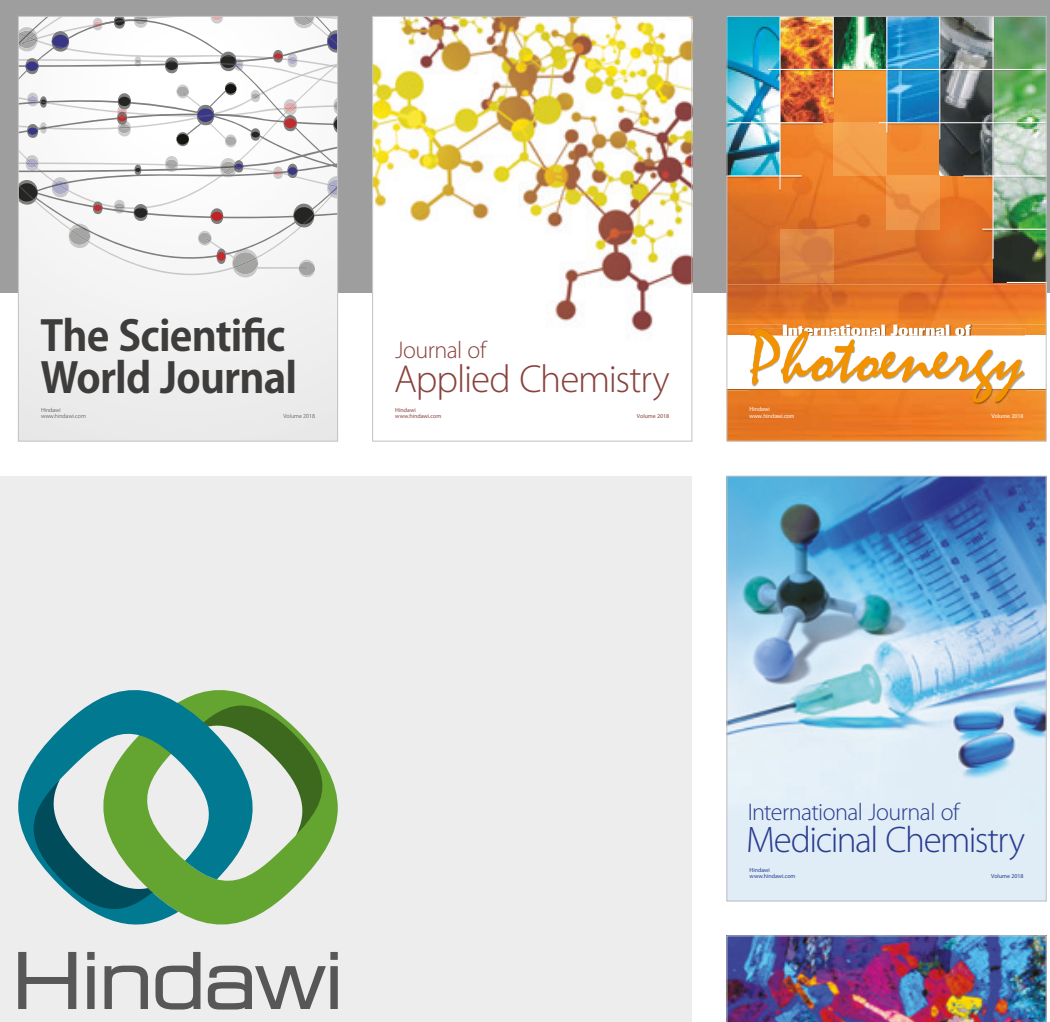

Submit your manuscripts at

www.hindawi.com
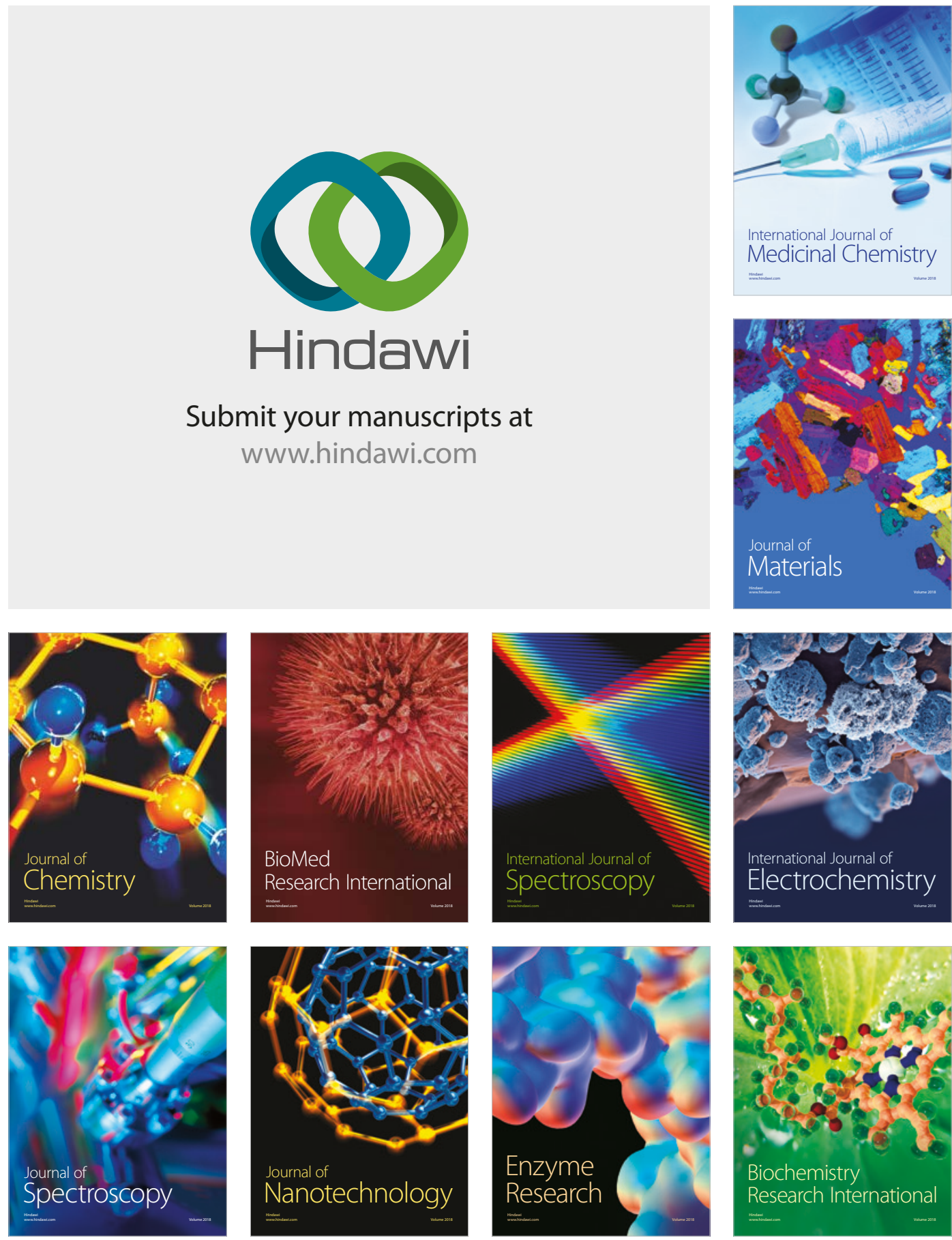
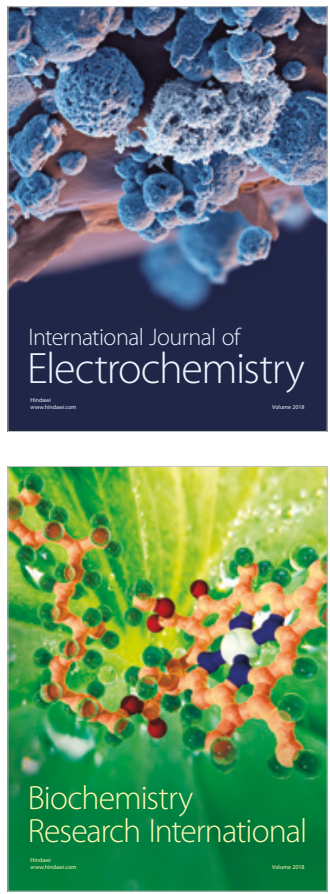